\title{
Urothelial Tumours of the Urinary Bladder: A Histopathological Study of Cystoscopic Biopsies
}

\author{
Sujan Vaidya, 'Mamta Lakhey, 'Sabira KC, ${ }^{2}$ Suspana Hirachand' \\ 'Department of Pathology, Kathmandu Medical College, Sinamangal, Kathmandu, ${ }^{2}$ Department of Pathology, Patan \\ Academy of Health Sciences, Lagankhel, Lalitpur, Nepal.
}

\section{ABSTRACT}

Introduction: Bladder tumours constitute one of the most common urological conditions. Urothelial (transitional cell) carcinoma accounts for $90 \%$ of all primary tumours of the bladder. These tumours are an important cause of morbidity and mortality. The objective of this study was to present the histopathological patterns of urothelial tumours and to determine the grade and stage of these tumours.

Methods: This is a 3 year descriptive study of urothelial tumours carried out in the Department of Pathology, Patan Academy of Health Sciences (PAHS), Lalitpur, Nepal. Data of all cystoscopic biopsies collected during this period were analyzed.

Results: Of the 83 urinary bladder tumours, 81 (97.59\%) cases were urothelial (transitional cell) tumours. Transitional cell carcinoma (TCC) was the most common bladder tumour which was seen in $67(80.72 \%)$ cases. Thirty two $(47.76 \%)$ cases of TCC were low grade while $35(52.24 \%)$ were high grade. Forty three $(64.18 \%)$ cases of TCC were superficial or in early stage (pTa and pT1) while 24 $(35.82 \%)$ showed muscle invasion.

Conclusions: Transitional cell carcinoma was the most common bladder cancer. Most of these tumours were high grade. A large percentage of high grade carcinomas presented with muscle invasion. Pathological grade and muscle invasion are the most valuable prognostic predictors of survival. The importance of including smooth muscle in the biopsy specimens needs to be emphasized.

Keywords: cancer; high grade; low grade; transitional tumour; urinary bladder.

\section{INTRODUCTION}

Bladder tumours constitute one of the most common urological conditions. ${ }^{1}$ The prevalence of these tumours is higher in developed countries as compared to developing countries. ${ }^{2}$ In the United States alone, an estimated 70,980 new cases were diagnosed with an estimated 14,330 deaths in $2009 .^{1}$ They are an important cause of both morbidity and mortality. ${ }^{3}$ In more than $75 \%$ of the patients, the most common sign is gross and microscopic haematuria. ${ }^{4}$

Correspondence: Dr. Sujan Vaidya, Department of Pathology, Kathmandu Medical College, Sinamangal, Kathmandu, Nepal. E-mail: vaidyasujan@gmail.com, Phone: 9841416529. 
Urothelial (transitional cell) tumours represent about $90 \%$ of all bladder tumours and run the gamut from small, benign lesions that might never recur to aggressive cancers associated with high risk of death. ${ }^{5}$ It affects men more often than women ( 3 to $4: 1$ ). ${ }^{3,6}$ About $80 \%$ of patients are between the ages of 50 and 80 years. $^{3}$ About $90 \%$ of bladder carcinoma reported from the West is of transitional cell type. ${ }^{7}$ In a large series reported from Egypt, squamous cell carcinoma (SCC) accounted for $59-73 \%$ of bilharzial bladder cases. $^{8}$

Important risk factors that have been implicated in the causation of bladder cancer include cigarette smoking, industrial exposure to arylamines, Schistosomahaematobium, long term use of analgesics, heavy long term exposure to cycophosphamides and prior exposure of the bladder to radiation. ${ }^{3}$

\section{METHODS}

This is a descriptive study carried out in the Department of Pathology, Patan Academy of Health Sciences (PAHS), Lalitpur, Nepal, over a period of 3 years from April 2010 to March 2013. Data of all cystoscopic biopsies done during this period were collected and analyzed using SPSS version 17.0.

The World Health Organization (WHO)/International Society of Urological Pathology (ISUP) classification (2004) was used to grade the tumours into: urothelial papilloma, papillary urothelial neoplasm of low malignant potential (PUNLMP), low and high grade urothelial (transitional cell) carcinomas (TCC). ${ }^{9}$ Pathological staging of the urothelial cancers was done according to the TNM system and data recorded as pTa: tumour limited to mucosa, pT1: invasion of lamina propria and pT2 as invasion of muscle. ${ }^{9}$

\section{RESULTS}

Total of 107 cystoscopic biopsies were analyzed. A spectrum of different pathological lesions was observed in the study (Table 1). Out of the 107 cases, 83 $(77.57 \%)$ cases were tumours while 21 (19.63\%) were inflammatory conditions (Table 2).

\begin{tabular}{|lc|}
\hline \multicolumn{1}{|c|}{ Table 1. Spectrum of different pathological lesions. } \\
\hline \multicolumn{1}{|c|}{ Diagnosis } & Total $(\%)$ \\
Cystitis & $16(14.95)$ \\
Haemorrhagic cystitis & $1(0.93)$ \\
Eosinophilic cystitis & $2(1.88)$ \\
Granulomatous cystitis & $1(0.93)$ \\
Schistosomiasis & $1(0.93)$ \\
Endometriosis & $1(0.93)$
\end{tabular}

\begin{tabular}{|lc|} 
Cystitis cystica & $2(1.88)$ \\
Urothelial papilloma & $3(2.81)$ \\
PUNLMP & $11(10.28)$ \\
Low grade urothelial carcinoma & $32(29.91)$ \\
High grade urothelial carcinoma & $35(32.71)$ \\
Adenocarcinoma & $1(0.93)$ \\
Small cell carcinoma & $1(0.93)$ \\
\multicolumn{1}{|c}{ Total } & $107(100)$ \\
\hline
\end{tabular}

Of the total 83 urinary bladder tumours, 81 (97.59\%) cases were urothelial (transitional cell) tumours. Transitional cell carcinoma (TCC) was the most common bladder tumour which was seen in $67(80.72 \%)$ cases. Of these, $32(47.76 \%)$ were low grade TCC while 35 $(52.24 \%)$ were high grade TCC. A case each of an adenocarcinoma and a small cell carcinoma were also seen (Table 2).

\begin{tabular}{|c|c|c|}
\hline & Lesion & Total (\%) \\
\hline Inflammation & & 21 (19.63) \\
\hline Metaplasia & & $2(1.87)$ \\
\hline Endometriosis & & $1(0.93)$ \\
\hline Tumours & & 83 (77.57) \\
\hline & Total & 107 \\
\hline
\end{tabular}

The median age at presentation of bladder tumours was 65 years (range: $16-88$ years) and its peak incidence was between $61-70$ years. Sixty eight (81.93\%) cases of bladder tumours were seen in males while 15 $(18.07 \%)$ were seen in females. Male to female ratio was 4.5:1 (Table 3).

\begin{tabular}{|lccc|}
\hline \multicolumn{4}{|l|}{$\begin{array}{l}\text { Table 3. Age and sex distribution of bladder } \\
\text { tumours. }\end{array}$} \\
\hline $\begin{array}{l}\text { Age group } \\
\leq 40\end{array}$ & Male (\%) & Female (\%) & Total (\%) \\
& $05(6.02)$ & $01(1.2)$ & $6(7.23)$ \\
$41-50$ & $04(4.83)$ & $01(1.2)$ & $5(6.02)$ \\
$51-60$ & $14(16.88)$ & $03(3.61)$ & 17 \\
$61-70$ & $23(27.73)$ & $05(6.02)$ & $28.48)$ \\
$71-80$ & $17(20.48)$ & $03(3.61)$ & 28 \\
$81-90$ & $05(6.02)$ & $02(2.4)$ & $7(8.44)$ \\
Total & $68(81.96)$ & $15(18.04)$ & $83(100)$ \\
\hline
\end{tabular}


Vaidya et al. UrothelialTumours of the Urinary Bladder: A Histopathological Study of Cystoscopic Biopsies

\begin{tabular}{|c|c|c|c|c|c|}
\hline \multicolumn{6}{|c|}{$\begin{array}{l}\text { Table } 4 \text {. Grading ar } \\
\text { tumours. }\end{array}$} \\
\hline Grade & \multicolumn{4}{|c|}{ Total } & $\%$ \\
\hline Papilloma & 03 & - & - & 03 & 03.7 \\
\hline \multirow[t]{3}{*}{ PUNLMP } & 11 & - & - & 11 & 13.58 \\
\hline & \multicolumn{3}{|c|}{ Stage } & & \\
\hline & pTa & pT1 & pT2 & & \\
\hline $\begin{array}{l}\text { Low grade } \\
\text { TCC }\end{array}$ & 21 & 07 & 04 & 32 & 39.51 \\
\hline $\begin{array}{l}\text { High grade } \\
\text { TCC }\end{array}$ & 04 & 11 & 20 & 35 & 43.21 \\
\hline Total & 39 & 18 & 24 & 81 & 100 \\
\hline
\end{tabular}

\begin{tabular}{|c|c|c|c|}
\hline \multirow[t]{2}{*}{ Grade } & \multicolumn{2}{|c|}{ Muscle invasion } & Total \\
\hline & Present & Absent & \\
\hline Low grade TCC & $04(16 \%)$ & $21(84 \%)$ & 25 \\
\hline High grade TCC & $20(76.92 \%)$ & $06(23.08 \%)$ & 26 \\
\hline Total & 24 & 27 & 51 \\
\hline
\end{tabular}

The WHO (2004)/ISUP classification of urothelial bladder tumours was used to grade the tumours (Table 4). Staging of TCC was done according to the TNM classification. Out of the 67 cases of TCC, $43(64.18 \%)$ were superficial /or in the early stage (pTa and pT1) and $24(35.82 \%)$ were muscle invasive (pT2).

The detrusor muscle was absent in 16 (23.88\%) cases of TCC. Hence, muscle invasion could only be assessed in the remaining 51 (76.12\%) cases. Four (16\%) cases of low grade and $20(76.92 \%)$ cases of high grade TCC showed muscle invasion (Table 5).

\section{DISCUSSION}

Neoplasms of the bladder are one of the commonest urological conditions. They are a heterogenous group of tumours with different subtypes and behavioural patterns. ${ }^{10}$ In the world literature, about $95 \%$ of bladder tumours are of epithelial origin, the remainder being mesenchymaltumours. Most epithelial tumours are composed of urothelial (transitional) type cells $(90 \%)$ and are thus interchangeably called urothelial (transitional cell) tumours, but squamous and glandular carcinomas also occur. ${ }^{3}$

Bladder cancer is the $7^{\text {th }}$ most common cancer worldwide, with an estimated 260,000 new cases occurring each year in men and $76,000 .{ }^{11}$ It is considerably more common in males than in females (ratio worldwide is 3 to $4: 1$ ). ${ }^{3,6}$

Cystoscopic biopsies of 107 patients included in this study revealed a spectrum of different pathological lesions. Bladder tumours were the most common type of lesion and was seen in $83(77.57 \%)$ cases, followed by $21(19.63 \%)$ cases of inflammation. All 83 cases of bladder tumours were of epithelial origin, of which $81(97.59 \%)$ were urothelial (transitional cell) tumours.

Transitional cell carcinoma (TCC) was the most common bladder neoplasm in our study and was diagnosed in $67(80.72 \%)$ cases. Similar data (81.81\%) was published by Mahesh et al. from India. ${ }^{2}$ In the western literature, these tumours account for $90 \%$ of bladder cancers. ${ }^{7}$ Small cell carcinoma and adenocarcinoma are uncommon tumours of the bladder and account for about 0.5 and $2 \%$ of all bladder cancers, respectively. ${ }^{12,13}$ In our study, $1(1.45 \%)$ case each of small cell carcinoma and an adenocarcinoma were seen.

The demographic characteristics of the patients in the current study were relatively similar to a number of previous studies which describe a peak incidence of bladder cancer in the seventh decade and predominance in men with male to female ratio of $4.5: 1 .{ }^{10,14,15}$ The median age of presentation of bladder cancer was 65 years in this study which is relatively similar to that reported in the existing literature. ${ }^{16-19} \mathrm{~A}$ higher incidence of bladder cancers in males than in females is probably related to difference in smoking habits and occupational exposure..$^{3,17}$

In our study, WHO (2004)/ISUP grading of urothelial tumours reveal a higher incidence of high grade TCC compared to low grade TCC. High grade TCC was seen in $35(43.21 \%)$ cases while $32(39.51 \%)$ cases were low grade TCC. This may be due to late presentation of the patient. Mahesh et al. ${ }^{2}$ also observed higher incidence of high grade TCC (53.57\%) compared to low grade TCC (42.85\%). However, a higher incidence of low grade TCC was revealed in studies by Laishramet al. ${ }^{16}$ and Ahmed et al. ${ }^{20}(53.85 \%$ and $44 \%$, respectively) compared to high grade TCC $(26.41 \%$ and $29.5 \%$, respectively).

Transitional cell carcinoma (TCC) was diagnosed in 67 cases in this study. Of these, 43 (64.18\%) were superficial /or in the early stage (pTa and pT1) while $24(35.82 \%)$ were muscle invasive (pT2). In studies by Gupta et al ${ }^{17}$ and Laishram et al $^{16}$ muscle invasion was seen in $26 \%$ and $30.77 \%$, respectively.

Tumour grading and staging are currently the two major factors for recurrence, progression and for determination of treatment options for patients with bladder carcinoma. ${ }^{18}$ In our study, the detrusor muscle was absent in the $16(23.88 \%)$ cases of TCC. Hence, muscle invasion could only be assessed in the remaining $51(76.12 \%)$ cases. Of the 51 cases of 
TCC, muscle invasion was seen in $4(16 \%)$ cases of low grade and $20(6.92 \%)$ cases of high grade TCC. Similar observation was also made by Laishram et al. (18\% and $75 \%$, respectively). ${ }^{16}$ Not including muscle layer in the cystoscopic biopsy specimens may lead to understaging of tumours in many patients. The importance of including smooth muscle in the biopsy specimens needs to be emphasized. ${ }^{16}$

\section{CONCLUSIONS}

In our study, bladder tumours were the commonest lesions seen in cystoscopic biopsies, most of which were of urothelial origin. Transitional cell carcinoma was the most common bladder tumour in our study. Most of these tumours were high grade. A large percentage of high grade transitional cell carcinomas presented with muscle invasion. Pathological grade and muscle invasion are the most valuable prognostic predictors of survival. The importance of including smooth muscle in the biopsy specimens needs to be emphasized.

\section{REFERENCES}

1. Jemal A, Siegel R, Ward E, Hao Y, Xu J, Thun MJ. Cancer statistics. CA Cancer J Clin. 2009;59:225-49.

2. Mahesh KU, Yelikar BR. Spectrum of lesions in cystoscopic bladder biopsies- A histopathological study. Al Ameen J Med Sci. 2012;5(2):132-6.

3. Epstein JI. The lower urinary tract and male genital system. In: Kumar V, Abbas AK, Fausto N,eds. Robbins and Cotran Pathologic Basis of Disease. 7th ed. Philadelphia: Saunders; 2004. p. 1023-58.

4. Murphy DM, Zincke H, Furlow WL. Management of high-grade transitional cell cancer of upper urinary tract. J Urol. 1981;125:25-9.

5. Murphy WM, Beckwith JB, Farrow GM. Tumours of the urinary bladder. In: Atlas of Tumour Pathology, $3^{\text {rd }}$ series, Fascicle 11. Washington D.C: Armed Forces Institute of Pathology; 1994. p. 193-297.

6. Parkin DM, Bray FI, Ferlay J, et al. Global Cancer Statistics, 2002. CA Cancer J Clin. 2005;55:74-108.

7. Schler HI, Shipley WU, Herr HW. Cancer of the bladder. In: De-Vita VT, ed. Cancer Principles and Practice of Oncology. $5^{\text {th }}$ ed. Philadelphia: Lippincott Raven; 1997. p. 1300.

8. El-Bolkainy MH, Mokhtar MN, Ghoneim MA, Hussein $\mathrm{MH}$. The impact of schistosomiasis on pathology of bladder carcinoma. Cancer. 1981;48:2643-5.

9. Eble JN, Sauter G, Epstein JI, Sesterhenn IA. Tumours of the urinary system, In: WHO Classification of Tumours Pathology and Genetics of Tumours of the Urinary System and Male Genital Organs. Lyon: IARC Press; 2004. p. 89-158.

10. N Husain, A Shumo, S Mekki, N Dawi, M Elsid. A Clinicopathological Study of Urinary Bladder Neoplasms in Patients at Three Centers in Khartoum, Sudan. Sudan Journal of Medical Science. 2009;4(3):249-55.
11. Parkin DM, Bray F, Ferlay J, Pisani P. Estimating the world cancer burden: Globocan 2000.Int J Cancer. 2001;94(2):153-6.

12. Blomjous CEM, Vos W, De Voogt HJ, Van Der Valk P, Meijer CILM. Small cell carcinoma of the urinary bladder, a clinicopathologic, morphometric immunohistochemical, and ultrastructural study of 18 cases. Cancer. 1989;64:1347-57.

13. Jacobo E, Loening S, Schmidt JD, Culp DA. Primary adenocarcinoma of the bladder: a retrospective study of 20 patients. J Urol. 1977;117:54-6.

14. Waihenya CG, Mungai PN. Pattern of transitional cell carcinoma of the urinary bladder as seen at Kenyatta National Hospital, Nairobi. East Afr Med J. 2004;981(3):114-19.

15. Mohammed SA. Genito-urinary cancer in Saudi Arabia. Saudi Medical Journal 2004;25(5):552-6.

16. Laishram RS, Kipgen P, Laishram S, Khuraijam S, Sharma DC. Urothelialtumours of the urinary bladder in Manipur: A histopathological perspective.Asian Pac J Cancer Prev. 2012;13(6):2477-9.

17. Gupta P, Jain M, Kapoor R, et al. Impact of age and gender on the clinicopathological characteristics of bladder cancer. Indian J Urol. 2009;25:207-10.

18. Matalka I, Bani-Hani K, Shotar A, Bani-Hani O, Bani-Hani I. Transitional cell carcinoma of the urinary bladder: Aclinicopathological study. Singapore Med J 2008;49(10):790-4.

19. Kong CH, Singam P, Hong GE, Cheok LB, Azrif M, Tamil AM, Zainuddin ZM. Clinicopathological features of bladder tumours in a single institution in Malaysia. Asian Pac J Cancer Prev. 2010;11(1):149-52.

20. Ahmed Z, Muzzafer S, Khan et al. Transitional cell carcinomas of urinary bladder. A histopathological study. J Pak Med Assoc. 2002;52:396-8. 